\title{
Reproductive biology of Triportheus trifurcatus (Castelnau, 1855) (Characiformes: Characidae) in the middle rio Araguaia, MT, Brazil
}

\author{
Mirian F. Martins-Queiroz ${ }^{1}$, Lúcia A. de F. Mateus², Valdener Garutti ${ }^{3}$ and \\ Paulo C. Venere ${ }^{1}$
}

The study of the reproductive biology of Triportheus trifurcatus of the middle rio Araguaia was carried out using 275 specimens obtained in seven collections conducted in the period between November 2003 and January 2005. Females prevailed among the classes of intermediate length, as well as in the total number of samples. On the other hand, males prevailed in the smaller classes. The average length of females was larger than that of males. Four stages of gonadal maturation were macro- and microscopically identified: B - maturation, C - mature, D - spent and E - resting. Stage A (immature) was not found in the habitats sampled. The smallest-length male was $110 \mathrm{~mm}$ in standard length, and the smallest female, $119 \mathrm{~mm}$. The spawning period occurred from November to January, with reproductive peak in December/January, coinciding with the highest water levels. The absolute fecundity is considered low, and there is a positive correlation between fecundity and gonad weight, body weight and standard length. Food ingestion during the reproductive period did not suffer any interference, and it is suggested complete spawning for this species.

A biologia reprodutiva de Triportheus trifurcatus, do médio rio Araguaia, é estudada com base em 275 exemplares obtidos em sete coletas, realizadas no período de Novembro/2003 a Janeiro/2005. Nas classes de comprimento intermediário e na amostragem geral, as fêmeas predominam, mas nas classes menores prevalecem os machos. As fêmeas se apresentam, na média, maiores que os machos. Quatro estádios de maturação gonadal são identificados, macro e microscopicamente: B- maturação, Cmaduro, D-esgotado/ espermiado e E- repouso. O estádio A (imaturo) não foi registrado nos biótopos amostrados. O menor exemplar macho maduro apresenta $110 \mathrm{~mm}$ e a menor fêmea $119 \mathrm{~mm}$ de comprimento padrão. O período de desova ocorre de Novembro a Janeiro, com pico reprodutivo em Dezembro/Janeiro coincidindo com os níveis mais elevados das águas. A fecundidade absoluta é considerada baixa e há correlação positiva entre fecundidade e peso das gônadas, peso corporal e comprimento padrão. A ingestão de alimento não sofre interferência durante o período reprodutivo e é sugerida desova total para a espécie em estudo.

Keys words: Fecundity, Sex ratio, Reproductive cycle, Gonadal maturation.

\section{Introduction}

The Neotropical ichthyofauna is the most diversified in the world, and is estimated to contain as many as 8,000 species (Schaefer, 1998). In contrast to its huge richness, basic biological knowledge is minimal for most of these species. The ichthyofauna of the Tocantins-Araguaia drainage is no exception. For example, systematized data about reproduction in a great number of species are not completely reliable. This has serious implications, such as contradictions in the assessment of the fishing resources.
The species of the genus Triportheus are among the fewest known so far. According to Soares \& Junk (2000), and Batista \& Petrere Jr. (2003), Triportheus spp. appeared to be a prominent species unloaded at the fish market of Manaus (AM), in the period of 1994-96. Lowe-McConnell (1999) also mentions that Triportheus represented one of the main genusfoods in the Manaus market, consumed especially when bigger fish were scarce. Although lacking official data, the species of Triportheus are broadly consumed, especially by the riverine communities of the Tocantins-Araguaia basin (based on personal observations as well as those of fisherman colonies).

\footnotetext{
${ }^{1}$ Universidade Federal de Mato Grosso, Instituto Universitário do Araguaia. Rodovia MT 100, Km 3,5. 78698-000 Pontal do Araguaia, MT, Brazil. pvenere@uol.com.br

${ }^{2}$ Universidade Federal de Mato Grosso, Instituto de Biociências, Avenida Fernando Correia da Costa s/n - Coxipó. 78060-900 Cuiabá, MT, Brazil.

${ }^{3}$ Pesquisador Visitante CNPq-UFMT-ICLMA. valdenergarutti@yahoo.com.br
} 
Information on the reproductive cycle are important for knowledge of the role and life history of the fish and are essential for the study of population dynamics, besides addressing conservation and management policies (Hartz et al., 1997). The purpose of the present work was to study the reproductive biology of Triportheus trifurcatus (Castelnau, 1855) in a sector of the middle rio Araguaia, with regard to their sex ratio, size of first sexual maturation, population structure, macro- and microscopic classification of the reproductive cycle stages, time and type of spawning, and fecundity. Food ingestion during the reproductive cycle was also investigated.

\section{Material and Methods}

Study area. The Tocantins-Araguaia hydrographic basin covers an area of 967,059 $\mathrm{km}^{2}$ and extends throughout the states of Goiás, Tocantins, Pará, Maranhão, Mato Grosso, and the Brazilian Federal District. In this system, the flood season lasts from October to April, with its peak in February, in the upper course, and March in the middle and lower courses.

During flooding, Araguaia and its main affluents, the rio das Mortes and rio Cristalino, form an enormous flood plain and reduce their water volume between May and September, with drought peaks in September.

Data collection and analysis. Samples of T. trifurcatus (according to Malabarba, 2004) were captured with fishhooks and gillnets, with mesh sizes varying from 20 to $70 \mathrm{~mm}$. The collections were made in the middle rio Araguaia, in the area called Travessão do Ouro Fino (1550'15"S - 5158'43"W) (Fig. 1) in the main channel and at the mouth of two small tributaries, Ouro Fino and Jacutinga streams, at intervals from 60 to 80 days, from November 2003 to January 2005. Voucher specimens are deposited in the fish collection of the Laboratory of Ichthyology of Instituto Universitário do
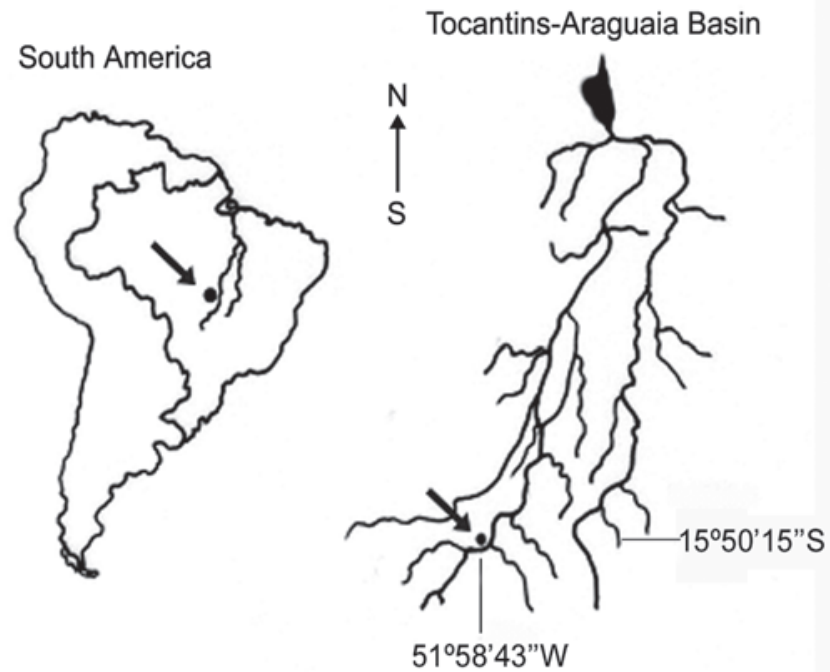

Fig. 1. Geographic location of the collection site of $T$. trifurcatus, in Travessão do Ouro Fino, middle rio Araguaia, MT.
Araguaia, Universidade Federal de Mato Grosso, Brazil (Series ICLMA065; ICLMA109, ICLMA172).

Water level measurements were obtained from the Defesa Civil de Cuiabá, MT, which in turn received the information from the Agência Nacional de Águas (ANA).

Information on standard length (SL; expressed in $\mathrm{mm}$ ), sex, gonad and body weights (WG, WB), and stomach weight (WS) as well (all weights expressed in g) of each fish specimen was obtained. Sex determination and the classification of the reproductive cycle stage were based on macro- and microscopic analysis of the gonads, according to Vazzoler (1996) and Narahara et al. (1988). Fragments of gonads were fixed in Bouin's solution for 8 to12 h, submitted to routine histological processing and stained with hematoxylin-eosin (HE). Gonads were then classified according to the following stages: B - maturation, C - mature, D-spent and E - resting. The sex ratio was determined by grouping the data obtained from 2003 to 2005, in length classes. The chi-square test $\left(X^{2}\right)$ was applied, assuming the expected proportion of 1:1 between males and females. Differences in the average length of males and females were tested using Student's t test.

Reproductive activity was evaluated according to the frequency of occurrence of the gonad maturation stages and temporary analysis of the gonadosomatic index (GSI = WG $\mathrm{x}$ 100/WB). Food ingestion during the stages of gonad maturation was analyzed according to the stomach weight index (SSI = WS x100/WB). Differences between the average values of GSI among periods, and SSI among maturation stages, were tested for males and females separately using analysis of variance (ANOVA). Data were transformed into natural logarithms so as to meet the assumption of normality. When significant differences were found, the Sheffé post hoc test was applied.

In each maturation stage, the oocytes were measured with the aid of ocular micrometric methods (100 times magnification), for the analysis of the size frequency distribution and determination of the spawning type. Ovaries of 10 females in stage C (mature) were put into Gilson solution for dissociation of the oocytes for subsequent counting. Fecundity was estimated according to Vazzoler (1996), with slight adaptations. Absolute fecundity (F) was obtained as follows: $F=(V n) / v$, where $F=$ total number of oocytes, $n=$ average number of oocytes obtained from the subsamples, $\mathrm{V}$ $=$ total solution volume, and $\mathrm{v}=$ subsample volume. The relationships between fecundity and length, fecundity and body weight, and fecundity and gonad weight were analyzed using simple linear regression. The statistical analyses were accomplished assuming a significance level of 0.05 .

\section{Results}

A total of 275 specimens of $T$. trifurcatus were collected in seven collections carried out in the middle rio Araguaia, of which 158 (57\%) were females and 117 (43\%) males. In January 2004, males prevailed $\left(X^{2}=6.533 ; p=0.0106\right)$, while in April 2004, females prevailed $\left(X^{2}=9.846 ; p=0.0017\right)$. Regarding the general 
sex ratio during the period between November 2003 and January 2005, the females prevailed. Females' length varied from 100 to $186 \mathrm{~mm}(137.2 \pm 11.5)$ and males' length, from 105 to $160 \mathrm{~mm}(126.7 \pm 10.0)$. Males prevailed in the smaller classes, while females prevailed in the intermediate classes. On average, females were larger than the males $(\mathrm{t}=7.93$; $\mathrm{p}<0.01$; degrees of freedom $=273$ ). The smallest mature female was $119 \mathrm{~mm}$, and the smallest male, $110 \mathrm{~mm}$ (Table 1 ).

Males and females were observed in stage B (maturation), $\mathrm{C}$ (mature), $\mathrm{D}$ (spent), and $\mathrm{E}$ (resting). Individuals in the stage A (immature) were not recorded during the study. Mature males were more frequent during the months of November 2003, January 2004, November 2004 and January 2005. Mature females were found more frequently in the month of November of 2003 and 2004. There were high frequencies of exhausted females during the month of January of 2004 and 2005. The temporary variation of the maturation stages showed a relationship with the change in the river water level. With the initial rains and flooding season, a relatively high number of mature fish could be observed already in November. Higher mature sampling frequencies occurred during flooding and during the dry season, where the majority of the individuals are resting.
GSI varied significantly among the sampling periods for females $\left(\mathrm{F}_{6: 148}=107.217\right.$ and $\left.\mathrm{p}<0.000\right)$, and males $\left(\mathrm{F}_{6} ;{ }_{97}=25.520\right.$ and $\mathrm{p}<0.000$ ) (Table 2). The highest values occurred during the month of November of 2003 and 2004 for females, and November 2003 and January 2004 for males (Fig. 2). The SSI values did not differ significantly between the maturation stages, for males $\left(\mathrm{F}_{3 ; 97}=2.161\right.$ and $\left.\mathrm{p}=0.097\right)$ or for females $\left(\mathrm{F}_{3,148}=1.769\right.$ and $\left.\mathrm{p}=0.155\right)$.

The distribution of oocyte size frequency appears to be of single modal type in stages $\mathrm{B}, \mathrm{D}$, and $\mathrm{E}$ and bimodal for $\mathrm{C}$, and provides evidence for the displacement of modals (Fig. 3). Larger oocytes were found in C and smaller in E, B and D, respectively (Table 3 ). The smallest type in stage $C$ represents the storage stock and the largest, mature oocytes.

Absolute fecundity varied from 3,533 to 13,833 oocytes, with an average of $7,920(s=3,472 ; n=10)$ and there was a positive relationship between this and standard length $(a=-$ $\left.348.54 ; \mathrm{b}=309.96 ; \mathrm{r}^{2}=0.58 ; \mathrm{p}=0.01 ; \mathrm{n}=10\right)$, body weight $(\mathrm{a}=-$ $\left.6,421.8 ; \mathrm{b}=266.95 ; \mathrm{r}^{2}=0.62 ; \mathrm{p}=0.006 ; \mathrm{n}=10\right)$, and gonad weight $\left(a=-898.19 ; b=2,548.6 ; r^{2}=0.78 ; p<0.001 ; n=10\right)$ (Fig. 4). The relative fecundity was 35.4 oocytes per mm in individuals of $125 \mathrm{~mm}$, and of 83.5 oocytes $/ \mathrm{mm}$ in specimens with $145 \mathrm{~mm}$ in length.

Table 1. Absolute frequency of standard length classes (SL) of T. trifurcatus from the middle rio Araguaia, from November 2003 to January $2005\left({ }^{*} \mathrm{p}<0.05,{ }^{* *} \mathrm{p}<0.01\right)$.

\begin{tabular}{ccccc}
\hline SL (mm) & Males & Females & $\mathbf{X}^{2}$ & P \\
\hline $100-115$ & 10 & 1 & 7.36 & $0.0067^{* *}$ \\
$115-130$ & 67 & 35 & 10.04 & $0.0015^{* *}$ \\
$130-145$ & 37 & 79 & 15.21 & $0.0001^{* *}$ \\
$145-160$ & 2 & 37.41 & $0.0000^{* *}$ \\
$160-175$ & 1 & 5 & 2.67 & 0.1025 \\
$175-190$ & 0 & 1 & 1.00 & 0.3173 \\
\hline$\Sigma$ & 117 & 158 & 6.11 & $0.0134^{*}$ \\
\hline
\end{tabular}
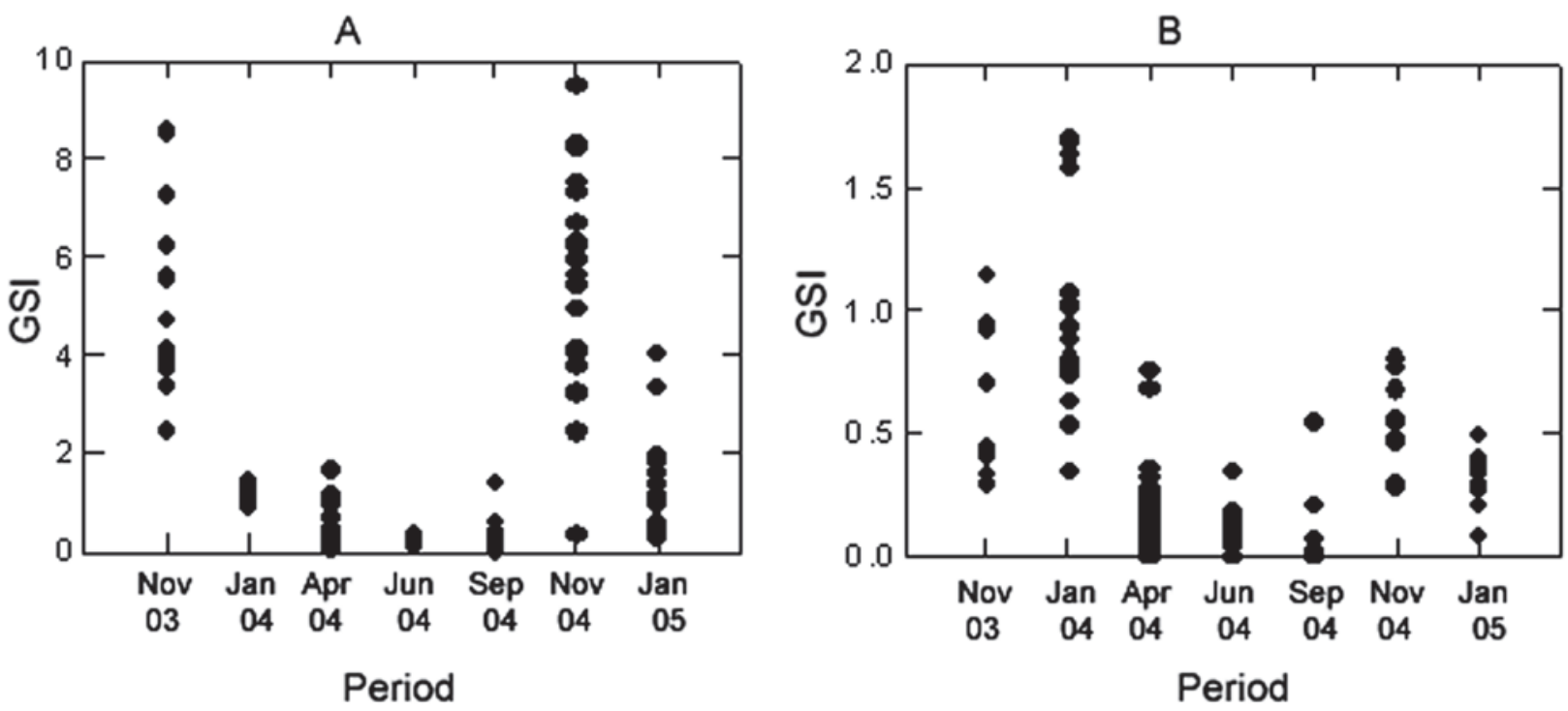

Fig. 2. Gonadosomatic index (GSI) for collections of females (A) and males (B) of T. trifurcatus of the middle rio Araguaia, from November 2003 to January 2005. 
Table 2. Number of individuals $(\mathrm{N})$, mean values and standard deviation of the gonadosomatic index (GSI) in each period for females and males of T. trifurcatus from the middle rio Araguaia, from November 2003 to January 2005. In the same column, different superscript letters indicate statistically significant differences $(\mathrm{p}<0.05)$.

\begin{tabular}{lllll}
\hline & \multicolumn{2}{l}{ Females } & \multicolumn{2}{l}{ Males } \\
\hline Period & $\mathrm{N}$ & GSI & $\mathrm{N}$ & GSI \\
\hline Nov/03 & 13 & $4.848 \pm 1.716^{\mathrm{a}}$ & 10 & $0.605 \pm 0.299^{\mathrm{a}}$ \\
Jan/04 & 8 & $1.164 \pm 0.209^{\mathrm{c}}$ & 22 & $0.975 \pm 0.410^{\mathrm{c}}$ \\
Apr/04 & 68 & $0.303 \pm 0.259^{\mathrm{b}}$ & 36 & $0.156 \pm 0.169^{\mathrm{b}}$ \\
Jun/04 & 7 & $0.220 \pm 0.086^{\mathrm{b}}$ & 15 & $0.114 \pm 0.078^{\mathrm{b}}$ \\
Sep/04 & 23 & $0.289 \pm 0.291^{\mathrm{b}}$ & 15 & $0.057 \pm 0.146^{\mathrm{ab}}$ \\
Nov/04 & 22 & $5.427 \pm 2.295^{\mathrm{ac}}$ & 11 & $0.529 \pm 0.168^{\mathrm{ac}}$ \\
Jan/05 & 17 & $1.509 \pm 0.980^{\mathrm{b}}$ & 8 & $0.309 \pm 0.123^{\mathrm{ab}}$ \\
\hline
\end{tabular}
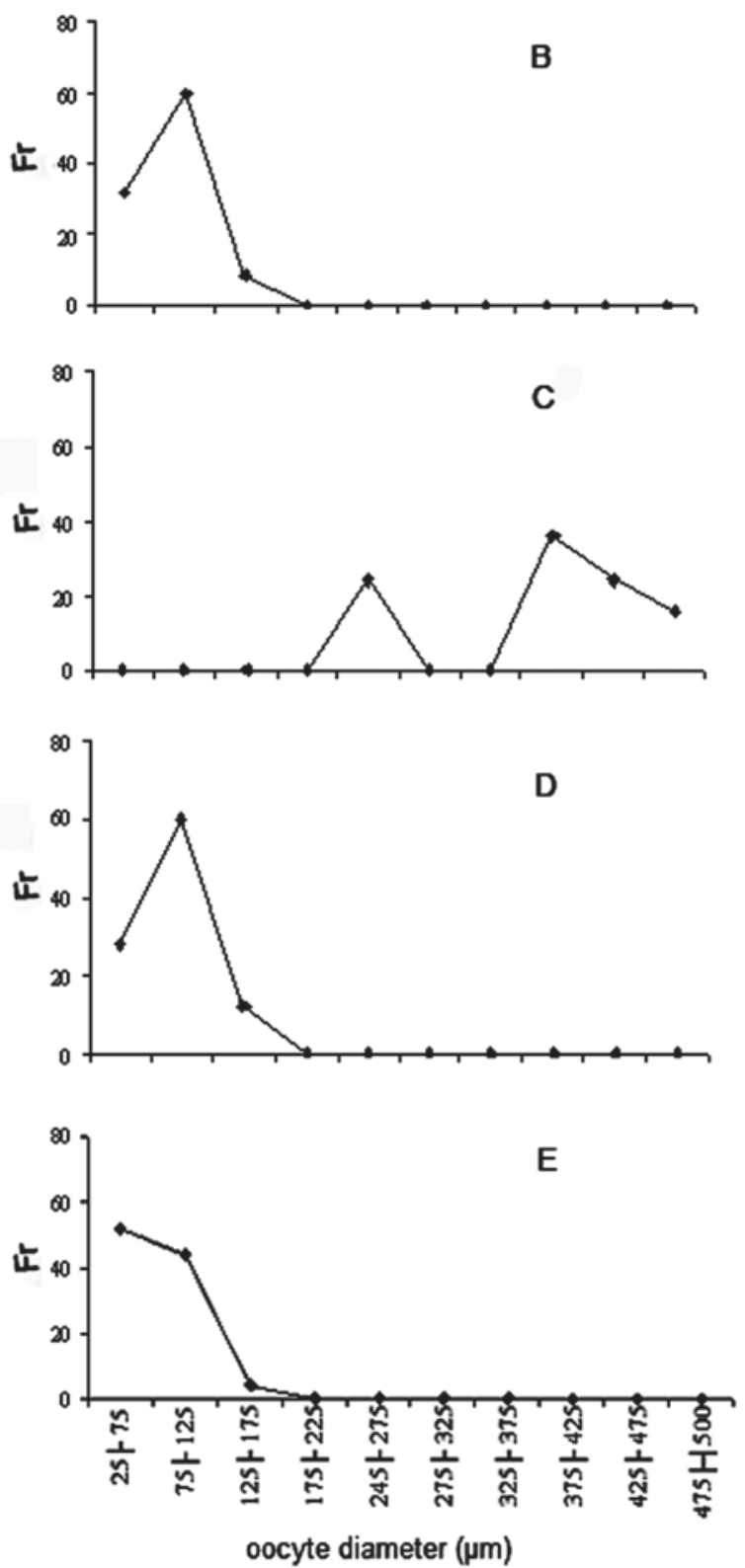

Fig. 3. Relative frequency (\%) of oocyte diameter classes $(\mu \mathrm{m})$ of T. trifurcatus females of the middle rio Araguaia, at maturation stages B, C, D and E.
Table 3. Means and standard deviation ( $\mathrm{X} \pm \mathrm{SD}$ ), minimum (Min.) and maximum (Max.) for size of oocytes per gonad maturation stage (GMS) in females of $T$. trifurcatus from the middle rio Araguaia.

\begin{tabular}{cccc}
\hline GMS & $\overline{\mathrm{X}} \pm \mathrm{SD}(\mu \mathrm{m})$ & Min. $(\mu \mathrm{m})$ & Max. $(\mu \mathrm{m})$ \\
\hline $\mathrm{B}$ & $87.50 \pm 24.74$ & 50.00 & 131.25 \\
$\mathrm{C}$ & $391.21 \pm 85.93$ & 250.00 & 499.00 \\
$\mathrm{D}$ & $89.25 \pm 24.64$ & 31.25 & 131.25 \\
$\mathrm{E}$ & $69.60 \pm 27.20$ & 25.00 & 125.00 \\
\hline
\end{tabular}
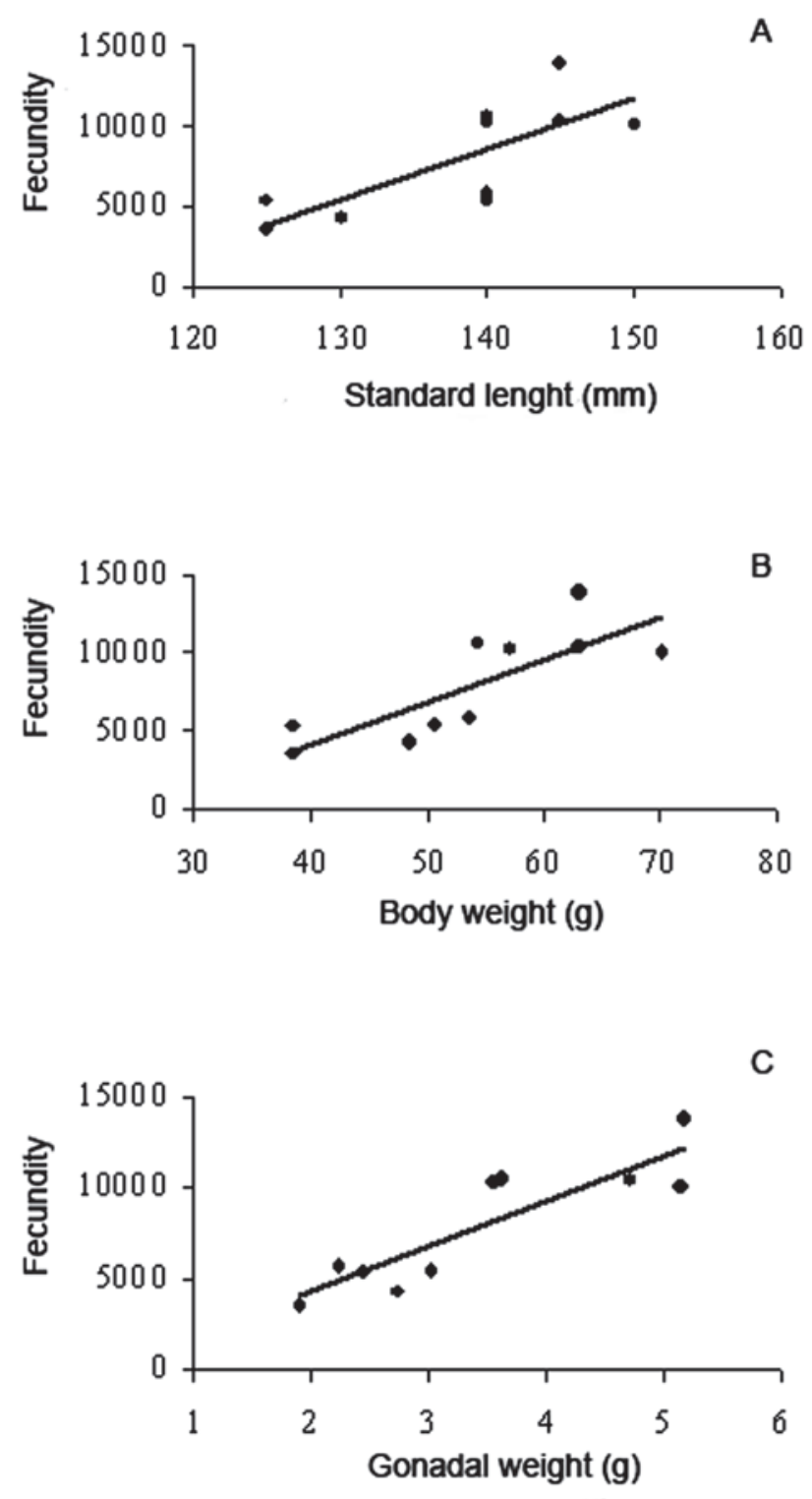

Fig. 4. Relationship between fecundity and standard length (A), body weight (B), and gonadal weight (C) for females of $T$. trifurcatus from the middle rio Araguaia. 


\section{Discussion}

The population of T. trifurcatus of the middle rio Araguaia showed a sex ratio of 1.3 female for each male of two females for each male. On only one occasion was the number of males higher than that of females, a period in which, apparently, spawning would have already happened (January) or would had happened recently. Wootton (1989) points out that some fish species with external fecundation, for example, $T$. trifurcatus, have a larger proportion of males during the peak of the reproductive cycle, when females show high fecundity indices. According to this author, such behavior could be advantageous considering that the males could fecundate a larger number of oocytes, thereby increasing the probability of perpetuation of the species. The sex ratio can also be influenced by environmental pressure factors (Veregue \& Orsi, 2003), as well as by behavioral aspects, due to a partial segregation of individuals of the two sexes (Hartz et al., 1997). In $T$. trifurcatus of the middle rio Araguaia, there are still differences regarding the frequency of males and females in length classes, which may indicate differentiated growth rates between sexes (Wootton, 1989).

The structure in length of $T$. trifurcatus shows that females reach a length larger than that of males, which is a common feature encountered among other teleost species [ $e$. g., Schizodon fasciatus Spix \& Agassiz, 1829, Rhytiodus argenteofuscus Kner, 1858, and R. microlepis Kner, 1858 (Santos, 1980); Pygocentrus piraya (Cuvier, 1819) (Cruz et al., 1996); Poecilia viviparous Bloch \& Schneider, 1801, Phalloptychus januarius (Hensel, 1868), and Jenynsia lineata (Jenyns, 1842)(Aranha \& Caramaschi, 1999); Colossoma macropomum (Cuvier, 1818) (Villacorta-Corrêa \& Saint-Paul, 1999); Leporinus friderici (Bloch, 1794) (Lopes et al., 2000)]. This type of dimorphism may be advantageous to the species. A larger asymptotic size in females may indicate a greater fecundity, since the number of oocytes is related to the increase in weight (Lowe-McConnell, 1999; Santos, 1980) or size, which is demonstrated in T. trifurcatus.

The size of the smallest female and male sample captured in the mature stage can be an indicative of the size of the first maturation (Bazzoli et al., 2003). The values found for $T$. trifurcatus in the middle rio Araguaia are smaller than the ones mentioned for the Imperatriz region (rio Tocantins), by Braga, (1990) (122 mm) and for the lower rio Tocantins, by Santos et al. (1984) (about $150 \mathrm{~mm}$ ).

The reproductive activity of $T$. trifurcatus is remarkably seasonal: peak occurrence of mature females coinciding with the highest water levels; spent females, with the decrease in water levels; and females in resting, when the waters reach their lowest levels. Surprisingly, immature specimens (A) (Vazzoler, 1996 and Narahara et al., 1988), were not collected in the sampled biotypes, indicating that they either occur in diverse biotypes or that the equipment used was not efficient for the capture of samples in this stage. We set out from the hypothesis that immature individuals occupy the flooded areas, especially temporary ponds, a fact common to numerous species of symptotic characiform fishes [e. g., Prochilodus nigricans Agassiz, 1829; Psectrogaster amazonica Eigenmann \& Eigenmann, 1889, Steindachnerina amazonica (Steindachner, 1911); Hemiodus unimaculatus (Bloch, 1794), Anodus orinocencis (Steindachner, 1887); Astyanax argyrimarginatus Garutti, 1999, A. elachylepis Bertaco \& Lucinda, 2005, Serrasalmus spilopleura Kner, 1858, Cynopotamus tocantinensis Menezes, 1987, Galeocharax gulo Cope, 1870, and Acestrorhynchus spp., among others]. The higher average GSI values occur during the flooding months. Thus, the reproductive activity peak of the species in question coincides with the raining season with high water levels, i.e., from November to January. These findings corroborate studies conducted in other areas, either for this or for any other similar species [Santos et al. (1984) in the lower rio Tocantins; Goulding (1979), in the rio Madeira; Braga (1990) in the Imperatriz-Estreito, rio Tocantins; Höfling et al. (2000), Salto Grande reservoir, rio Paranapanema].

According to Vazzoler \& Menezes (1992), the reproductive cycles may be synchronized with the seasons in response to the environmental conditions, whose rhythms involve endogenous and exogenous factors. In accordance with these authors, unlike food availability, photoperiod and temperature should not be limiting factors in reproduction of tropical fish. The food amount increases with the increment of the water level, when floods enlarge the environment and provide for shelter and food appropriate for the initial phases of development (Vazzoler \& Menezes, 1992, Lowe-McConnell, 1999). In T. trifurcatus, the data presented here demonstrate that the higher offer is not reflected in higher food ingestion by the adult samples. Neither a possible decrease in feeding rhythm nor an interruption of ingestion during reproduction or particularly at the reproductive peak was corroborated. Goulding (1980) reported that T. angulatus (Spix \& Agassiz, 1829) and T. elongatus [T. culter (Cope, 1872)] do not feed when migrating in the rio Madeira.

The mature gonad stage and the higher GSI values occur in a short period of the year. In the mature stage, the distribution of oocytes is still bimodal, while in the other stages of the reproductive cycle the distribution of oocytes sizes is unimodal. This finding suggests that this species shows complete spawning in this environment.

Fecundity and the variables gonad weight, standard length and body weight show a positive correlation in $T$. trifurcatus of the middle rio Araguaia. The greatest correlation is seen between fecundity and gonad weight. As previously mentioned, the relationship fecundity/length found in $T$. trifurcatus indicates that larger females produce more oocytes, but when compared to the other migrating Characiformes, their total fecundity is considered low [e.g., Curimatus gilbert (=Cyphocharax gilberti) (Quoy \& Gaimard, 1824): 12,749 to 75,734 (Romagosa et al., 1984); C. modestus (Fernández-Yepes, 1948): 9,760 to 93,280 Barbieri \& Hartz, 1995); Semaprochilodus brama (Valenciennes, 1850): 136,922 to 48,154 and Anodus sp.: 63,162 to 144,600).

The present study on $T$. trifurcatus shows a positive 
relationship between rainfall and water levels, with the peak of the reproductive period coinciding with the rainy season. Therefore, measures that guarantee the protection of the stock in the process of reproduction during the period from November to January are of fundamental importance for population balance in this environment, as well as for the preservation and the increment in current fish stocks.

\section{Acknowledgments}

The authors are thankful to the fishermen Jason L. de Oliveira and Humberto P. Rego for their help with the capture of the samples, to IBAMA, Gerex of Barra do Garças, MT, and SEMA - Regional of Barra do Garças, MT for logistical support. FAPEMAT provided financial aid which has been continually helpful in the development of this and other works on the Araguaia valley, and CNPq granted a Visiting Scientist Scholarship to one of the authors. A. Leyva helped with English editing of the manuscript.

\section{Literature Cited}

Aranha, J. M. R. \& E. P. Caramaschi. 1999. Estrutura populacional, aspectos da reprodução e alimentação dos Cyprinodontiformes (Osteichthyes) de um riacho do sudeste do Brasil. Revista Brasileira Zoologia, 16(1): 637-651.

Araújo, S. A. \& H. C. B. Gurgel. 2002. Aspectos da biologia de Prochilodus cearensis (Steindachner, 1911) (Characiformes, Prochilodontidae) no açude Itans/Caicó, Rio Grande do Norte. Revista Brasileira de Zoociências, 4 (1): 85-96.

Barbieri, G. \& S. Hartz. 1995. Estudo da fecundidade e tamanho de primeira maturação gonadal de Cyphocharax modesta (HENSEL, 1869) da represa do Lobo, estado de São Paulo, Brasil (Characiformes, Curimatidae). Comunicações do Museu de Ciências e Tecnologia da PUCRS, Série Zoologia, 8: 27-35.

Batista, V. S. \& M. Petrere Júnior. 2003. Characterization of the commercial fish production landed at Manaus, Amazonas State, Brazil. Acta Amazonica, 33 (1): 53-66.

Bazzoli, N. 2003. Parâmetros reprodutivos de peixes de interesse comercial do rio São Francisco na região de Pirapora. In: Godinho, H. P. \& Godinho, A. L. (org.). Águas, peixes e pescadores do rio São Francisco das Minas Gerais. PUC Minas, Belo Horizonte, 468p.

Braga, F. M. de S. 1990. Aspectos da reprodução e alimentação de peixes comuns em um trecho do rio Tocantins entre Imperatriz e Estreito, Estados do Maranhão e Tocantins, Brasil. Revista Brasileira de Biologia, 50(3): 547-548.

Cruz, A. M. G., Y. Sato, E. Rizzo, G. B. Santos \& N. Bazzoli. 1996. Maturação sexual da piranha Pigocentrus piraya (CUVIER, 1820) (Pisces, Characidae) na represa de Três Marias, Minas Gerais. Bios. Cadernos do Departamento de Ciências Biológicas da PUC Minas Gerais, 4(4): 1721.

Goulding, M. 1979. Ecologia da pesca do rio Madeira. Manaus, Amazonas, $172 \mathrm{p}$.

Goulding, M. 1980. The Fishes and the Forest: Explorations in Amazonian Natural History. University of California Press. Berkeley. 280p.
Hartz, S. M., F. S. Vilela \& G. Barbieri. 1997. Reproduction dynamics of Oligosarcus jenynsii (Characiformes, Characidae) in lake Caconde, Rio Grande do Sul. Brazil. Revista Brasileira de Biologia, 57(2): 295-303.

Höfling, J. C., L. I. Ferreira, F. D. Ribeiro-Neto, R. B. Bertolim.\& A. B. Berlluzzo. 2000. Distribuição, reprodução e alimentação de Triportheus signatus (Triportheus angulatus) no reservatório de Salto Grande, Bacia do rio Piracicaba, SP, Brasil. Bioikos, PUC-Campinas, 14(1): 16-23.

Lopes, C. de A., E. Benedito-Cecílio \& A. A. Agostinho. 2000. The reproductive strategy of Leporinus friderici (Characiformes, Anostomidae) in the Paraná river basin: the effect of reservoirs. Revista Brasileira de Biologia, 66(2): 255-266.

Lowe-McConnell, R. H. 1999. Estudos ecológicos de comunidades de peixes tropicais. São Paulo, Edusp. 535 p.

Malabarba, M. C. S. L. 2004. Revision of the Neotropical genus Triportheus Cope, 1872 (Characiformes: Characidae). Neotropical Ichthyology, 2(4):167-204.

Narahara, M. Y., M. A. Basile-Martins, H. P. Godinho \& M. N. Cipólli. 1988. Escala de maturidade, época de reprodução e influência de fatores abióticos sobre o desenvolvimento gonadal de Rhamdia hilarii (Valenciennes, 1840). Boletim do Instituto de Pesca, 15(2): 201-211.

Romagosa, E., H. M. Godinho \& M. Y. Narhara. 1984. Fecundidade e tipo de desova de Curimatus gilberti da Represa de Ponte Nova, Alto Tiête. Revista Brasileira de Biologia, 44 (1): 1-7.

Santos G. M. 1980. Estudo da reprodução e hábitos reprodutivos de Schizodon fasciatus, Rhytiodus microlepis e R. argenteofuscus (Pisces, Anostomidae) do lago Janauacá. Acta Amazônica, 10(2): 391-400.

Santos, G. M., M. Jegu \& B. Merona. 1984. Catálogo de peixes comerciais do baixo Tocantins. INPA: Manaus. 84 p.

Schaefer, S. A. 1998. Conflict and resolution: impact of new taxa on phylogenetic studies of the neotropical cascudinhos. p. 375400. In: Malabarba et al. (Ed.). Phylogeny and classification of neotropical fishes: Edipucrs, Porto Alegre. 603p.

Soares, M. G. M. \& W. J. Junk. 2000 . Commercial fishery and fish culture of the state of Amazonas: Status and Perspectives. In: W.J. Junk; J.J. Ohly; M.T.F. Piedade; M.G.M. Soares. (Org.). The Central Amazon Floodplain: Actual Use and Options for a Sustainable Management. Leiden: Backhuys Publishers, 1: 433-461.

Vazzoler, A. E. A. de M. 1996. Biologia da reprodução de peixes Teleósteos: teoria e prática. Maringá: Eduem, SBI.169 p.

Vazzoler, A. E. A. de M. \& N. A. Menezes.1992. Síntese de conhecimentos sobre o comportamento reprodutivo dos Characiformes da América do Sul (Teleostei, Ostariophysi). Revista Brasileira de Biologia, 52(4): 627-640.

Veregue, A. M. L. \& M. L. Orsi. 2003. Biologia reprodutiva de Astyanax scabripinnis paranae (Eigenmann) (Osteichthyes, Characidae), do ribeirão das Marrecas, bacia do rio Tibagi. Paraná. Revista Brasileira de Zoologia, 20 (1):97-105.

Villacorta-Correa, M. A. \& U. Saint-Paul. 1999. Structural indexes and sexual maturity of tambaqui Colossoma macropomum (Cuvier, 1918) (Characiformes: Characidae) in Central Amazon, Brazil. Revista Brasileira de Biologia, 59(4): 637-652.

Wootton, R. J. 1989. Fishes reproduction: strategies and tactics. In: Ecology of teleost fishes. New York, Kluwer Academic Publishers, $2^{\mathrm{a}}$ ed. 386 p. 